\title{
PERLINDUNGAN HAK-HAK BURUH PADA PRAKTIK SISTEM OUTSOURCING: SEBUAH "KESENJANGAN PENERIMAAN"
}

\author{
Nafila \\ Fakultas Hukum Universitas Pancasila \\ Jalan Srengseng Sawah, Jagakarsa, Jakarta Selatan \\ nafilazmh@gmail.com \\ Erlin Kristine \\ Fakultas Hukum Universitas Pancasila \\ Jalan Srengseng Sawah, Jagakarsa, Jakarta Selatan \\ erlinkristine@gmail.com \\ Endra Wijaya \\ Fakultas Hukum Universitas Pancasila \\ Jalan Srengseng Sawah, Jagakarsa, Jakarta Selatan \\ endra.wijaya333@yahoo.co.id
}

\begin{abstract}
Nowadays, outsourcing becomes a common system which is used in many business entities. Some people thought that outsourcing could make business run more effectively and efficiently, while the others believe that outsourcing could be an unfavorable condition for labors/workers. However, Indonesian law system still accommodates business entities to use outsourcing in their business. This article focused on how outsourcing was implemented, and in the same situation, how the labors respond it. This article is based on field study, in which it gave attention to the implementation of outsourcing system in two different work units within the same institution, a private university in Jakarta. This study shows, in fact, through its practice, Indonesian labor law which rules outsourcing system has not been implemented effectively, so the labor would become the weak party before the bosses. And also, because of some reasons, the labors still agree to accept their unfavorable position when they were working under the outsourcing system.
\end{abstract}

Keywords: Outsourcing; Employment Contract; Labor Rights Protection

\begin{abstract}
Abstrak
Outsourcing atau alih daya merupakan sistem yang sudah banyak digunakan pada entitas usaha. Sebagian pihak menganggap dengan outsourcing efisiensi dalam proses usaha dapat tercapai, tetapi bagi sebagian pihak yang lain, outsourcing justru dianggap merugikan buruh. Secara yuridis, telah ada beberapa peraturan perundang-undangan di Indonesia yang mengakomodasi diperbolehkannya menerapkan sistem outsourcing. Artikel ini difokuskan
\end{abstract}


pada permasalahan praktik sistem outsourcing, bagaimana sistem outsourcing itu dijalankan, dan bagaimana buruh outsourcing yang ada di dalam sistem tersebut meresponsnya. Artikel ini disusun berdasarkan penelitian yang mengamati penerapan sistem outsourcing di dua unit kerja yang berbeda, namun masih berada dalam satu lembaga pendidikan tinggi yang sama. Penelitian ini memperlihatkan, dalam praktiknya, beberapa peraturan perundang-undangan yang mengatur mengenai outsourcing masih belum dilaksanakan secara maksimal, sehingga buruh semakin berada dalam posisi yang kurang beruntung saat mereka bekerja dalam sistem outsourcing. Selain itu, karena alasan-alasan tertentu, buruh ternyata tetap ada yang mau menerima pemberlakuan sistem outsourcing.

Kata Kunci: Outsourcing; Perjanjian Kerja; Perlindungan Hak-Hak Buruh

\section{A. PENDAHULUAN}

Suatu perjanjian, sebagaimana yang tercantum dalam Pasal 1313 Burgerlijk Wetboek (BW) adalah "suatu perbuatan dengan mana satu orang atau lebih mengikatkan dirinya terhadap satu orang lain atau lebih". Perjanjian yang dibuat itu lalu berlaku sebagai suatu undang-undang bagi pihak yang saling mengikatkan diri, serta mengakibatkan timbulnya suatu hubungan antara kedua pihak tersebut (Asyrof, 2003: 6).

Perjanjian juga merupakan suatu tindakan yang sangat dibutuhkan oleh seseorang dalam memenuhi kelangsungan hidupnya. Melalui perjanjian, satu pihak dapat mengadakan kerja sama dengan pihak lain, seperti halnya dalam dunia pekerjaan, sesorang bisa menggunakan perjanjian untuk mengikatkan dirinya dengan orang lain, dan perjanjian itu disebut perjanjan kerja. Seperti halnya perjanjian kerja dalam Pasal 1 angka 14 Undang-Undang Nomor 13 Tahun 2003 tentang Ketenagakerjaan adalah perjanjian antara pekerja atau buruh dengan pengusaha atau pemberi kerja yang memuat syarat-syarat kerja, dan hak dan kewajiban para pihak.

Undang-Undang Nomor 13 Tahun 2003 merupakan salah satu undang-undang yang mengatur masalah ketenagakerjaan dengan tujuan agar para tenaga kerja dan buruh dapat terpenuhi hak-hak dan mendapatkan perlindungan yang mendasar serta pada saat yang bersamaan dapat mewujudkan kondisi yang kondusif bagi pengembangan dunia usaha. Sebagaimana diatur dalam undang-udang tersebut perjanjian kerja itu bersifat memaksa, artinya para pihak dalam perjanjian kerja tidak dapat membuat perjanjian yang menyimpang dari peraturan perundangundangan ketenagakerjaan. Aturan tersebut telah diatur sedemikian rupa agar tercipta hubungan antara pihak buruh dan perusahaan yang harmonis dan saling tidak merugikan.

Tetapi apabila melihat fakta yang ada, masih banyak perjanjian kerja yang dibuat justru menimbulkan ketidak adilan, di mana satu pihak mendapatkan 
keuntungan dan pihak lainnya merasa dirugikan. Ketimpangan ini kecenderungannya sering dirasakan oleh pihak buruh (Triyono, 2011: 49-50 \& 52). Banyak buruh yang telah dirugikan karena perjanjian kerja, seperti pemberian upah yang tidak sesuai Upah Minimum Regional (UMR), waktu kerja yang lebih dari batasan yang diatur dalam perundang-undangan, jaminan sosial yang tidak dipenuhi oleh perusahaan, atau adanya praktik outsourcing, yang walaupun merugikan para buruh, baik dari segi ketidakjelasan status dan sebagainya, tetapi masih diterapkan hingga saat ini (Triyono, 2011: 49-50 \& 52; Andina, 2013: 12).

Outsourcing atau alih daya adalah suatu perjanjian yang dibuat antara pengusaha dengan pekerja, di mana perusahaan tersebut dapat menyerahkan sebagian pelaksanaan pekerjaan kepada perusahaan lainnya melalui perjanjian pemborongan pekerjaan yang dibuat secara tertulis. Outsourcing merupakan suatu sistem kerja yang oleh sebagian pihak dianggap merugikan pihak buruh, karena perjanjian kerja outsourcing adalah perjanjian yang tidak seimbang. Padahal dalam hakikatnya, perjanjan kerja harus dapat memberikan seperangkat hak dan kewajiban yang timbal balik di antara para pihaknya (tidak saling merugikan).

Secara praktik, ada beberapa penyimpangan yang dilakukan oleh perusahaan pemberi pekerjaan maupun perusahaan penyedia tenaga kerja terhadap sistem kerja outsourcing. Penyimpangan-penyimpangan tersebut, antara lain, ialah sebagaimana dipaparkan di bawah ini:

1. perusahaan pemberi pekerjaan tidak mematuhi syarat-syarat yang ditetapkan untuk jenis pekerjaan yang dapat di-outsource-kan seperti yang telah diatur dalam Pasal 65 ayat (2) Undang-Undang Nomor 13 Tahun 2003 tentang Ketenagakerjaan (M. Pakpahan dan D.R. Pakpahan, 2010: 110; Mebang, 2015: 1406). Menurut kajian St. Laksanto Utomo, salah satu penyebab terjadinya penyimpangan ini adalah karena perbedaan penafsiran jenis-jenis pekerjaan apa saja yang boleh di-outsource-kan (Utomo, 2014: 6 \& 10).

2. Kedua, perusahaan juga melanggar tentang batas waktu kerja yang ditetapkan bagi buruh. Pasal 59 ayat (1) butir 2 Undang-Undang Nomor 13 Tahun 2003 menyebutkan bahwa pekerjaan waktu tertentu paling lama 3 (tiga) tahun, namun banyak perusahaan yang terus memperpanjang waktu tersebut tanpa mengangkat buruh menjadi karyawan tetap. Dengan kata lain, dalam praktik outsourcing, juga akan menimbulkan permasalahan mengenai status buruh (Utomo, 2014: 8). Selanjutnya, sebagaimana hasil kajian dari Siti Kunarti (2009: 74), hal tersebut dapat berdampak pula pada persoalan lainnya, yaitu ketidakjelasan pengembangan diri, keahlian, atau karir dari buruh yang terikat perjanjian outsourcing.

3. Ketiga, perjanjian kerja dibuat sepihak atau tanpa proses kesepakatan yang seimbang, di mana pekerja tidak diberi tahu isi perjanjian kerja, pekerja tidak diberikan fasilitas kesehatan, uang makan dan/atau uang lembur. Bahkan, dalam praktik outsourcing di beberapa tempat, ditemukan pula fakta bahwa 
para buruh yang terikat perjanjian outsourcing dilarang untuk ikut dalam aktivitas serikat buruh (Kunarti, 2009: 7-8).

4. Keempat, terdapat sejumlah perusahaan penyedia kerja yang mengutip uang dari buruh outsourcing dengan berbagai alasan (Munir, 2014: 84-85).

Pada pihak lain, sistem kerja outsourcing menurut para pengusaha merupakan cara yang paling efisien dalam pengurangan biaya produksi. Karena mereka lebih sedikit atau bahkan tidak mengeluarkan biaya untuk tunjangan-tunjangan karyawan. Sistem kerja outsourcing, dalam peraturannya, hanya boleh diberlakukan pada pekerjaan sampingan, seperti tugas bidang keamanan, catering dan cleaning service. Salah satu alasan perusahaan tetap melakukan outsourcing ialah agar dapat mengurangi dan mengendalikan biaya operasional.

Berdasarkan ketimpangan tersebut di atas, artikel ini membahas bagaimana praktik 2 (dua) perjanjian outsourcing diterapkan pada sebuah lembaga perguruan tinggi swasta, dalam hal ini yang berbentuk universitas. Kedua perjanjian outsourcing tersebut berbeda dalam beberapa hal, dan diterapkan pada 2 (dua) tempat unit kerja yang berbeda pula. Terhadap kedua perjanjian outsourcing itu ternyata mendapat respons "penerimaan" yang berbeda dari masing-masing buruh yang menandatangani perjanjian outsourcing. Berdasarkan latar belakang seperti telah dipaparkan di atas, maka permasalahan yang mengemuka adalah: pertama, apakah praktik outsourcing yang dilakukan di 2 (dua) unit kerja di sebuah universitas yang diteliti sudah sesuai dengan Undang-Undang Nomor 13 Tahun 2003 tentang Ketenagakerjaan? Kedua, bagaimanakah perbandingan praktik outsourcing di kedua unit kerja itu? Lalu, bagaimanakah respons dari buruh-buruh outsourcing tersebut?

\section{B. METODOLOGI PENELITIAN}

Dasar penulisan artikel ini ialah penelitian lapangan. Penelitian tersebut untuk melihat bagaimana sebuah produk hukum yang substansinya sama, yang dalam hal ini berupa perjanjian outsourcing, diberlakukan pada tempat yang berbeda. Perjanjian outsourcing itu lalu dianalisis kesesuaiannya dengan peraturan perundang-undangan yang berlaku, dan juga dilihat bagaimana perjanjian outsourcing itu direspons oleh subjek hukum yang ikut menandatangani perjanjian, yang dalam hal ini ialah pihak buruh. Oleh karenanya, metode penelitian yang digunakan dalam menyusun artikel ini terdiri dari 2 (dua) metode penelitian sekaligus, yaitu metode normatif dan juga metode empiris.

Metode penelitian normatif dalam penelitian ini mengacu pada dilakukannya analisis terhadap kesesuaian antara perjanjian outsourcing dengan peraturan perundang-undangan yang berlaku, yaitu antara lain dengan Undang-Undang Nomor 13 Tahun 2003. Kemudian, metode penelitian empiris dalam penelitian ini mengacu pada upaya melihat bagaimana perjanjian outsourcing yang diteliti 
"diterima" oleh buruh, sebagai salah satu pihak yang ikut menandatangani perjanjian tersebut.

Untuk melengkapi data penelitian, peneliti melakukan wawancara dengan responden yang relevan, dalam hal ini ialah dengan beberapa buruh yang terikat dengan perjanjian outsourcing. Wawancara dilakukan oleh peneliti pada akhir tahun 2015. Untuk melihat relevansinya dengan keadaan sekarang, pada bulan November 2017, peneliti telah melakukan konfirmasi ulang dengan beberapa responden yang peneliti wawancarai dulu, dan hasilnya ialah bahwa informasi yang mereka berikan pada tahun 2015 tersebut masih tetap sama atau belum berubah. Setelah data diperoleh, peneliti menganalisis data dengan menggunakan metode pendekatan komparatif dan kualitatif.

Metode komparatif dilakukan dengan membandingkan 2 (dua) perjanjian kerja yang berasal dari 2 (dua) unit kerja, yaitu unit kerja di rektorat dan di fakultas dalam 1 (satu) institusi perguruan tinggi swasta di Jakarta. Substansi kedua perjanjian tersebut merupakan bentuk perjanjian outsourcing. Selain itu, dibandingkan juga bagaimana "penerimaan" para buruh terhadap perjanjian outsourcing yang mereka tanda tangani.

Analisis dalam penelitian ini bersandar pada data yang diperoleh dari dokumen, informasi dari wawancara, dan bukan bersandar pada data numerik (angka). Begitu pun dalam penyajian hasil akhir dari analisis, dituangkan dalam bentuk kalimat yang di dalamnya terdapat argumentasi yang diupayakan memadai untuk menjawab pokok permasalahan yang diajukan dalam penelitian ini. Oleh karena itu, jika mau dikategorikan metode analisis data yang digunakan dalam penelitian ini, maka ia termasuk ke dalam kategori analisis data secara kualitatif.

Lokasi penelitian yang dipilih oleh peneliti ialah sebuah universitas swasta di Jakarta, yang dalam artikel ini disebut sebagai US. Pada perguruan tinggi US terdapat beberapa unit kerja yang menerapkan sistem outsourcing, dan untuk penelitian ini, unit kerja yang dipilih hanya 2 (dua), yaitu unit kerja tingkat rektorat dan unit kerja tingkat fakultas. Selanjutnya, kedua unit kerja itu disebut sebagai Rektorat US dan Fakultas US.

\section{PEMBAHASAN}

\section{Dasar Pemikiran}

Outsourcing atau biasa disebut dengan alih daya adalah suatu perjanjian yang dibuat antara pengusaha dengan buruh, di mana perusahaan tersebut dapat menyerahkan sebagian pelaksanaan pekerjaan kepada perusahaan lainnya melalui perjanjian pemborongan pekerjaan yang dibuat secara tertulis. Alih daya merupakan penyerahan wewenang dari suatu perusahaan kepada perusahaan lain untuk menjalankan sebagian atau seluruh proses fungsi usaha dengan menetapkan suatu target atau tujuan tertentu (Yasar, 2011: 5). 
Hanya saja, dalam Undang-Undang Nomor 13 Tahun 2003 tidak ada istilah outsourcing yang terungkap secara eksplisit. Pasal 64 Undang-Undang Nomor 13 Tahun 2003 menyebut outsourcing dengan istilah pemborongan pekerjaan atau pengalihan jasa pekerja atau buruh. Berdasarkan Pasal 64 Undang-Undang Nomor 13 Tahun 2003 diatur bahwa, "perusahaan dapat menyerahkan sebagian pelaksanaan pekerjaan kepada perusahaan lainnya melalui perjanjian pemborongan pekerjaan atau penyediaan jasa pekerja/buruh yang dibuat secara tertulis."

Perjanjian yang mirip dengan outsourcing di dalam BW dapat ditemukan pengaturannya pada Pasal 1601, walaupun memang istilah outsourcing-nya tidak muncul secara eksplisit. Pasal 1601 b BW menjelaskan bahwa perjanjian pemborongan (outsourcing) adalah "suatu perjanjian di mana pemborong mengikat diri untuk menyelenggarakan suatu pekerjaan bagi pihak lain, yaitu pihak yang memborongkan pekerjaan dengan bayaran tertentu" (Kunarti, 2009: 68).

Khairani (2014: 810-811), dalam kajiannya mengenai kedudukan outsourcing setelah keluarnya Putusan Mahkamah Konstitusi Nomor 27/PUU-IX/2011, memberikan definisi outsourcing melalui ilustrasi yang ia deskripsikan sebagai berikut:

"secara sederhana outsourcing dapat diilustrasikan dengan adanya suatu perusahaan penyedia jasa pekerja yang merekrut calon pekerja untuk ditempatkan di perusahaan pengguna tetapi pekerja memiliki hubungan kerja hanya dengan perusahaan jasa pekerja. Hubungan hukum antara perusahaan penyedia jasa pekerja dengan perusahaan pengguna pekerja dilakukan berdasarkan sebuah perikatan. Perusahaan penyedia jasa pekerja mengikatkan dirinya untuk menempatkan pekerja di perusahaan pengguna dan perusahaan pengguna mengikatkan dirinya untuk menggunakan pekerja tersebut. Berdasarkan perjanjian penempatan tenaga kerja, perusahaan penyedia jasa pekerja akan mendapatkan sejumlah uang dari pengguna”.

Pola perjanjian kerja dalam bentuk outsourcing secara umum ialah ada beberapa pekerjaan dari suatu perusahaan kemudian diserahkan ke perusahaan lain yang telah berbadan hukum, di mana perusahaan yang satu tidak berhubungan secara langsung dengan buruh yang bekerja, tetapi hanya kepada perusahaan penyalur atau pengerah tenaga kerja. Jadi, di dalam pola outsourcing, terdapat 3 (tiga) unsur subjek hukum (perusahaan, perusahaan penyedia outsourcing, dan buruh outsourcing (Kunarti, 2009: 70-71).

\section{Pengaturan Outsourcing dalam Perundang-Undangan}

Pasal-pasal yang mengatur mengenai outsourcing di antaranya ialah sebagai berikut: Pasal 64 Undang-Undang Nomor 13 Tahun 2003 yang menyatakan bahwa, "Perusahaan dapat menyerahkan sebagian pelaksanaan pekerjaan kepada perusahaan lainnya melalui perjanjian pemborongan pekerjaan atau penyediaan jasa pekerja atau buruh yang dibuat secara tertulis". Selain itu, dalam Pasal 65 
Undang-Undang Nomor 13 Tahun 2003 juga diatur beberapa hal lagi mengenai outsourcing, antara lain:

a. Perjanjian outsourcing dibuat secara tertulis.

b. Pekerjaan yang dapat dijadikan sebagai substansi perjanjian outsourcing harus memenuhi syarat-syarat sebagai berikut:

1) Dilakukan secara terpisah dari kegiatan utama;

2) Dilakukan dengan perintah langsung atau tidak langsung dari pemberi pekerjaan;

3) Merupakan kegiatan penunjang perusahaan secara keseluruhan; dan

4) Tidak menghambat proses produksi secara langsung.

c. Hubungan kerja dalam outsourcing dapat didasarkan atas perjanjian kerja waktu tidak tertentu atau perjanjian kerja waktu tertentu.

Selanjutnya, Pasal 66 Undang-Undang Nomor 13 Tahun 2004 juga mengatur lagi beberapa hal tentang perjanjian outsourcing. Pasal 66 ini telah memuat aturan mengenai perlunya upaya ikut mensejahterakan buruh yang terikat dengan perjanjian outsourcing. Pasal 66 ayat (2) huruf c menjelaskan bahwa, "perlindungan upah dan kesejahteraan, syarat-syarat kerja, serta perselisihan yang timbul menjadi tanggung jawab perusahaan penyedia jasa pekerja atau buruh; ..."

Selain Undang-Undang Nomor 13 Tahun 2003, BW juga mengatur mengenai penerapan outsourcing atau pemborongan pekerjaan yang tercantum dalam Pasal $1601 \mathrm{~b}$ BW. Pasal $1601 \mathrm{~b}$ mengatur bahwa outsourcing atau pemborongan pekerjaan merupakan suatu perjanjian di mana pemborong mengikat diri untuk membuat suatu kerja tertentu bagi pihak lain yang memborongkan mengikatkan diri untuk memborongkan pekerjaan kepada pihak pemborong dengan bayaran tertentu.

Pengaturan lebih rinci mengenai pemborongan pekerjaan dalam BW tercantum dalam Pasal 1604 sampai dengan Pasal 1617 BW. Pengaturan lainnya mengenai outsourcing terdapat pada Pasal 2 Keputusan Menteri Tenaga Kerja dan Transmigrasi Nomor KEP.101/MEN/VI/2004 tentang Tata Cara Perizinan Perusahaan Penyedia Jasa Pekerja atau Buruh, dan Keputusan Menteri Tenaga Kerja dan Transmigrasi Nomor KEP. 220/MEN/X/2004 tentang Syarat-Syarat Penyerahan Sebagian Pelaksanaan Pekerjaan kepada Perusahaan Lain.

\section{Pro dan Kontra terhadap Outsourcing}

Saat ini, banyak pihak pengusaha lebih memilih untuk menggunakan sistem kerja kontrak, walaupun pilihan itu menyebabkan adanya pro dan kontra. Kebijakan pemerintah yang memperbolehkan untuk menerapkan sistem kerja kontrak dan outsourcing di Indonesia di satu sisi menguntungkan pihak pengusaha. Hal ini karena pihak pengusaha tidak perlu dibebankan lagi kewajiban untuk memberikan kepastian mengenai pekerjaan si pegawai atau buruh tersebut, berbagai jaminan dan tunjangan pegawai itu pun bukanlah menjadi tanggung jawab dari perusahaan yang menggunakan jasa tenaga kerja ini. Sehingga dari sudut pandang pihak 
pengusaha, outsourcing dianggap dapat menjadikan perusahaan lebih efektif dan efisien dalam menjalankan aktivitas bisnisnya (Triyono, 2011: 53-54).

Sementara di sisi lain, pihak buruh merasa dirugikan karena tidak memiliki kekuatan hukum. Ini dapat dilihat pada perjanjian yang sejak awal cenderung menekan para buruh untuk tidak bisa menuntut apapun dari perusahaan dengan menggunakan surat perjanjian. Selain itu, para buruh pun tidak memiliki rasa aman dan sejahtera selama bekerja, karena mereka selalu dibebani oleh pikiran akan dipecat secara tiba-tiba oleh perusahaan pengguna jasa tenaga kerja outsourcing. Sebagaimana hasil kajian dari Bambang Nopiando (2012: 5), faktor rasa aman (pikiran yang tidak terbebani) akan berkorelasi secara positif dengan kinerja dari para buruh yang bekerja di suatu perusahaan. Faktor rasa aman tersebut sebenarnya bisa dimulai sejak proses dibuatnya (ditandatanganinya) kontrak kerja antara buruh dan perusahaan.

Pro dan kontra dari adanya sistem outsourcing dapat ditelusuri pada spesifikasi berikut:

\section{a. Pro}

Meski bagi sebagian pihak outsourcing merupakan hal yang sangat merugikan, namun bagi sebagian pihak yang lain pemborongan pekerjaan bisa menjadi suatu hal yang bermanfaat. Dalam Putusan Mahkamah Konstitusi, yaitu Putusan Perkara Nomor 012/PUU-I/2003, ada semacam "pembelaan" terhadap pemberlakuan sistem outsourcing atau alih daya, dengan alasan agar pengusaha dapat melakukan aktivitas bisnis mereka dengan efisien. Hal tersebut dianggap dapat menarik investasi dan pada akhirnya juga akan berpengaruh positif terhadap berjalannya roda perekonomian atau roda dunia usaha yang bisa menambah lapangan pekerjaan. Justru apabila kepentingan pengusaha tidak terakomodasi dengan baik, maka hal itu dapat menyebabkan ketiadaan investasi yang bisa menyebabkan berkurangnya lapangan kerja yang justru merugikan pihak buruh itu sendiri (Arizona, Wijaya, \& Sebastian, 2014: 83; Julianti, 2015: 28-29).

Menurut Iftida Yasar, beberapa manfaat dari alih daya antara lain ialah (Yasar, 2011: 6-8):

1) Bagi pemerintah, adanya sistem outsourcing dapat mengembangkan dan mendorong pertumbuhan ekonomi masyarakat serta pertumbuhan ekonomi nasional. Begitu pun akan berpengaruh positif terhadap upaya pembinaan dan pengembangan kegiatan koperasi serta usaha kecil dan menengah (UKM) dengan tumbuhnya perusahaan alih daya.

2) Masih bagi pemerintah, adanya outsourcing juga dapat membantu mengurangi beban pemerintah dalam mengatasi pengangguran dan perluasan kesempatan kerja.

3) Bagi masyarakat, aktivitas industri yang berjalan dengan baik tentu akan mendorong pula kegiatan ekonomi penunjang di level 
masyarakat, seperti pasar, warung, transportasi, dan lain-lain. Selain itu, hal tersebut juga akan ikut membantu mengembangkan infrastuktur sosial masyarakat, budaya kerja, disiplin, peningkatan pendidikan seiring dengan peningkatan kemampuan ekonomi, mengurangi pengangguran, dan mencegah terjadinya urbanisasi.

4) Bagi entitas industri, outsourcing dapat membantu meningkatkan fleksibilitas dalam pengembangan produk baru dan penyesuaian dengan pengembangan teknologi, sehingga perusahaan dapat berkonsentrasi untuk mengembangkan produk baru. Hal tersebut tentu juga akan berpengaruh positif terhadap upaya meningkatkan daya saing perusahaan dengan efisiensi penggunaan sumber daya yang dimiliki.

Apabila dicermati keempat alasan yang diajukan oleh Iftida Yasar tersebut, maka dapat diketahui bahwa manfaat dari outsourcing sebenarnya bisa dirasakan baik oleh pihak pemerintah, masyarakat pada umumnya, maupun pengusaha. Manfaat outsourcing tidak melulu hanya bisa dirasakan oleh pengusaha, karena bagi pemerintah dan masyarakat, tempat dari mana buruh berasal, mereka juga dapat merasakan atau memperoleh dampak positifnya, antara lain, yaitu berupa berkembangnya pertumbuhan ekonomi nasional, berkurangnya beban pemerintah dalam mengatasi pengangguran, dan bagi masyarakat, karena aktivitas industri berjalan relatif baik, tentu hal ini akan mendorong pula tumbuh berkembangnya kegiatan ekonomi di masyarakat.

\section{b. Kontra}

Kondisi perburuhan Indonesia saat ini sangat rentan, penuh ketidakpastian dan kapan saja buruh dapat terancam pemutusan hubungan kerja (PHK). Beberapa pihak menganggap sistem outsourcing merupakan sistem yang memberikan ketidakpastian status bagi buruh, sehingga mereka selalu berada di dalam ancaman PHK (Utomo, 2014: 9). Bahkan, tidak salah pula jika outsourcing ini dianggap sebagai sebuah mekanisme yang menciptakan viktimisasi struktural (Munir, 2014: 90).

Dalam kriminologi, viktimisasi struktural merupakan sebuah konsep untuk menjelaskan proses terjadinya korban kejahatan yang bersifat sistemik, di mana negara sebagai pihak yang memegang kendali kekuasaan punya peran dalam proses tersebut. Artinya, viktimisasi struktural merupakan proses munculnya korban yang berakar dari stratifikasi, nilai-nilai, dan institusi-institusi yang terdapat dalam masyarakat, termasuk institusi atau lembaga dalam pengertian negara atau hukum. Dengan demikian, realitas viktimisasi struktural berada dalam dimensi terselubung yang secara fisik tidak tampak sebagaimana kejahatan konvensional (Munir, 2014: 79).

Dalam viktimisasi struktural, dalam konteks outsourcing, maka subjek yang menjadi korbannya ialah para buruh yang bekerja dalam sistem outsourcing tersebut. Mereka cenderung tidak berdaya (tidak memiliki posisi tawar), bahkan 
tidak mengetahui realitas dirinya sendiri sebagai korban, sehingga akan selalu berada dalam posisi menerima kenyataan yang ada (Munir, 2014: 88).

Sistem outsourcing semakin marak dilakukan oleh para pengusaha. Data dari beberapa kajian menunjukkan bahwa penggunaan buruh outsourcing jumlahnya sudah mencapai lebih dari 50\% bila dibandingkan dengan persentase buruh bukan outsourcing (Andina, 2013: 9; Mebang, 2015: 1398). Banyaknya penggunaan buruh outsourcing itu tidak terlepas dari peluang yang diberikan oleh Undang-Undang Nomor 13 Tahun 2003 yang di dalamnya mengakomodasi sistem outsourcing (Soegianto dan Sutanto, 2013: 27; Mebang, 2015: 1398). Padahal kebolehan seperti itu justru memberikan peluang kepada para pengusaha untuk tidak melakukan amanat dalam Pembukaan serta Pasal 27 ayat (2) Undang-Undang Dasar Negara Republik Indonesia Tahun 1945 (Arizona, Wijaya \& Sebastian, 2014: 85). Konstitusi Indonesia telah mengamanatkan sekaligus menjamin bahwa setiap warga negara kedudukannya sama dalam hukum dan pemerintahan, serta mereka berhak pula atas pekerjaan dan penghidupan yang layak.

\section{Analisis Terhadap 2 (Dua) Praktik Outsourcing}

Penelitian ini menemukan adanya 2 (dua) perjanjian outsourcing yang dibuat untuk pekerjaan di lingkungan Rektorat US dan Fakultas US. Keduanya dibuat dengan mengacu pada peraturan perundang-undangan, antara lain, yaitu UndangUndang Nomor 13 Tahun 2003, Keputusan Menteri Tenaga Kerja dan Transmigrasi Nomor KEP.101/MEN/VI/2004 tentang Tata Cara Perizinan Perusahaan Penyedia Jasa Pekerja atau Buruh, dan Keputusan Menteri Tenaga Kerja dan Transmigrasi Nomor KEP.220/MEN/X/2004 tentang Syarat-Syarat Penyerahan Sebagian Pelaksanaan Pekerjaan Kepada Perusahaan Lain.

Selain peraturan perundang-undangan tersebut, pada masing-masing unit kerja, yaitu di unit kerja rektorat dan fakultas, praktik outsourcing-nya juga mendasarkan diri pada beberapa ketentuan yang berlaku secara internal khusus di lingkungan US, yaitu:

a. Praktik outsourcing di Rektorat US diberlakukan juga berdasarkan pada Peraturan Rektor US, dan perjanjian kerja. Perjanjian kerja yang dimaksud ialah perjanjian kerja yang terdiri dari 2 (dua) macam perjanjian, yaitu perjanjian kerja antara pihak US dan CV. AD sebagai penyedia buruh outsourcing, dan perjanjian kerja antara US dan buruh yang ditempatkan di US.

b. Praktik outsourcing di Fakultas US diterapkan pula berdasarkan pada perjanjian kerja yang dibuat antara pihak Fakultas US, Koperasi Fakultas US sebagai penyedia buruh di unit kerja Fakultas US, dan buruh yang bekerja di unit tersebut.

Telah dijelaskan bahwa praktik outsouring menimbulkan berbagai pro dan kontra di tengah masyarakat. Banyak pihak yang setuju mengenai pemborongan 
pekerjaan karena dianggap lebih efisien, tetapi di sisi lain, banyak pula pihak yang menentang pengalihan pekerjaan ini karena dianggap memberikan ketidakpastian terhadap buruh sehingga outsourcing ini sama saja dengan "perbudakan modern." Untuk memahami keadaan pro dan kontra yang telah tergambar, peneliti melakukan wawancara dengan beberapa buruh outsourcing di kedua unit kerja yang diteliti, yaitu di Rektorat US dan di Fakultas US. Di bawah ini adalah deskripsi dari pendapat-pendapat para responden yang telah peneliti wawancarai.

Berdasarkan keterangan dari buruh A1 yang bertugas di bidang kebersihan di Rektorat US, ia menjelaskan bahwa ia sudah bekerja selama lebih dari 3 (tiga) tahun. Sebagai petugas kebersihan di lingkungan Rektorat US, ia berpendapat bahwa selama ia bekerja di unit kerja rektorat hanya mendapatkan gaji sebesar $\mathrm{Rp}$ 938.000,00 (sembilan ratus tiga puluh delapan ribu rupiah), dan dengan gaji sebesar itu, ia menganggap belum bisa memenuhi kebutuhan hidup saat ini (wawancara, 16 November 2015 dan November 2017).

Jumlah gaji yang diterima oleh buruh A1 tampak masih belum sesuai dengan apa yang tertuang di Pasal 88 ayat (1) dan Pasal 89 Undang-Undang Nomor 13 Tahun 2003, bahwa setiap buruh berhak memperoleh penghasilan yang memenuhi penghidupan yang layak bagi kemanusiaan. Seperti yang tertuang di dalam Pasal 88 Undang-Undang Nomor 13 Tahun 2003, seharusnya upah minimum bagi setiap buruh harus sesuai dengan upah minimum berdasarkan wilayah provinsi atau kabupaten/kota, di mana upah minimum regional Jakarta pada tahun 2015 adalah sebesar Rp 2.700.000,00 (dua juta tujuh ratus ribu rupiah) (Kisihandi, 2015). Sementara upah minimum pada tahun 2017 berdasarkan Pasal 1 Peraturan Gubernur Provinsi Daerah Khusus Ibukota Jakarta naik menjadi Rp 3.335.750,00 (tiga juta tiga ratus lima puluh lima rupiah). Artinya, upah yang diterima buruh outsourcing yang bekerja di unit kerja Rektorat US masih belum sesuai dengan peraturan perundang-undangan.

Berdasarkan keterangan dari buruh A2 yang juga sebagai petugas kebersihan di unit kerja Rektorat US, ia menjelaskan kepada peneliti bahwa ia hanya mendapatkan upah sebesar Rp 36.000,00 (tiga puluh enam ribu rupiah) per hari, apabila terdapat hari libur nasional dan ada ketidakhadiran tanpa keterangan, maka upah yang harusnya sebesar Rp 975.000,00 (sembilan ratus tujuh puluh lima ribu rupiah), jika hadir penuh selama 26 (dua puluh enam) hari selama sebulan, akan berkurang karena adanya pemotongan upah (wawancara, November 2015 dan November 2017). Selain upah yang tentu saja di bawah upah minimum regional Jakarta pada tahun 2015 dan tahun 2017, fakta ini juga sangat memprihatinkan dikarenakan masih adanya pemotongan terhadap upah tersebut.

Peneliti juga mewawancarai buruh A1, buruh A2, dan buruh A3 mengenai jaminan sosial sebagai buruh outsourcing. Menurut ketiga responden, bahwa selama mereka bekerja sebagai buruh outsourcing di Rektorat US mereka tidak pernah 
mendapatkan jaminan sosial ketenagakerjaan (JAMSOSTEK), padahal berdasarkan Pasal 99 Undang-Undang Nomor 13 Tahun 2003 tentang Ketenagakerjaan dikatakan bahwa setiap pekerja atau buruh beserta keluarganya berhak untuk memperoleh jaminan sosial tenaga kerja.

Selain itu, hal lain yang mereka utarakan juga adalah mengenai masalah tunjangan hari raya yang nilainya belum sesuai dengan peraturan perundangundangan, di mana buruh outsourcing di Rektorat US hanya mendapatkan tunjangan hari raya sebesar Rp 350.000,00 (tiga ratus lima puluh ribu rupiah). Jumlah itu sangat jauh berbeda dengan nilai satu bulan dari gaji mereka, bahkan tidak sampai setengah dari gaji yang dapat mereka peroleh apabila bekerja full selama satu bulan, padahal dalam Pasal 4, Pasal 6, dan Pasal 7 Peraturan Pemerintah Nomor 78 Tahun 2015 tentang Pengupahan telah diatur bahwa setiap pekerja berhak diberikan tunjangan hari raya oleh pengusaha. Sementara mengenai besaran dari tunjangan hari raya tersebut diatur dalam Pasal 3 Peraturan Menteri Tenaga Kerja Nomor PER-04/MEN/1994, yaitu sebesar upah satu bulan kerja (untuk saat ini, diatur dalam Peraturan Menteri Ketenagakerjaan Nomor 6 Tahun 2016 tentang Tunjangan Hari Raya Keagamaan bagi Pekerja/Buruh di Perusahaan).

Pada sesi wawancara lain, peneliti mewawancarai beberapa buruh outsourcing yang unit kerjanya berada di sebuah fakultas, namun masih dalam satu universitas yang sama, yaitu US. Peneliti mewawancarai 3 (tiga) orang petugas kebersihan yang bekerja sebagai buruh outsourcing di unit kerja Fakultas US. Buruh B1 yang peneliti wawancarai menjelaskan bahwa ia telah bekerja sebagai cleaning service dan ia mendapatkan upah sebesar Rp 1.000.000,00 (satu juta rupiah) per bulan tanpa pemotongan upah, kecuali jika ia tidak hadir tanpa adanya keterangan yang jelas (wawancara November 2015 dan November 2017).

Sebagai buruh outsourcing, B1 dan kawan-kawannya ditempatkan di unit kerja Fakultas US, namun mereka merupakan buruh outsourcing dari Koperasi Fakultas US. Upah mereka sebagai buruh outsourcing diberikan oleh Koperasi Fakultas US tersebut. Upah yang diberikan oleh pihak Koperasi Fakultas US memang masih belum memenuhi standar seperti yang diatur dalam Pasal 88 dan Pasal 89 Undang-Undang Nomor 13 Tahun 2003, di mana upah minimum bagi setiap pekerja haruslah sesuai dengan upah minimum berdasarkan wilayah provinsi atau kabupaten/kota, yaitu sebesar Rp 2.700.000,00 (dua juta tujuh ratus ribu rupiah), untuk tahun 2015. Meskipun demikian, buruh B1 yang juga merupakan mantan buruh outsourcing di unit kerja Rektorat US, di mana ia berada di bawah CV. AD sebagai penyedia jasa buruh outsourcing, mengaku lebih menyukai dan merasa nyaman saat bekerja selama 2 (dua) tahun belakangan ini di bawah naungan Koperasi Fakultas US sebagai penyedia jasa buruh outsourcing untuk unit kerja Fakultas US.

Masih menurut buruh B1, pihak Koperasi Fakultas US mempunyai kepedulian yang tinggi terhadap buruhnya, di sini juga ia merasakan suatu kebersamaan baik 
dengan sesama buruh maupun atasannya, hal itu dapat dibuktikan dengan adanya kegiatan olah raga sepak bola bersama para buruh dan atasan yang diadakan seminggu sekali. Sementara menurut petugas kebersihan yang lain, yaitu buruh B2, , ia mengungkapkan bahwa selama ia bekerja di Koperasi Fakultas US dan ditempatkan di unit kerja Fakultas US, ia mendapatkan upah sebesar Rp 1.175.000,00 (satu juta seratus tujuh puluh lima ribu rupiah). Jumlah itu tentu belum sesuai dengan jumlah yang diatur dalam perundang-undangan, yaitu dengan acuan upah minimum regional Jakarta tahun 2015, lebih-lebih upah minimum regional Jakarta tahun 2017. Tetapi meskipun begitu, buruh B2 mengaku sudah mensyukuri upah yang saat ini ia peroleh. Sebelum bekerja di bawah naungan Koperasi Fakultas US, ia merupakan buruh outsourcing di unit kerja Rektorat US yang berada di bawah naungan perusahaan alih daya CV. AD. Saat buruh B2 bekerja di bawah naungan CV. AD, ia hanya mendapatkan upah sebesar Rp 800.000,00 (delapan ratus ribu rupiah). Jumlah tersebut didapatkan buruh B2 jika dalam satu bulan ia hadir selama 26 (dua puluh enam) hari penuh, jika terdapat hari libur nasional, maka upahnya akan dipotong (wawancara, November 2015 dan November 2017).

Berdasarkan keterangan petugas kebersihan yang lain, yaitu buruh B3, yang juga merupakan buruh outsourcing di bawah naungan Koperasi Fakultas US dan ditempatkan di unit kerja Fakultas US, peneliti mendapat penjelasan bahwa ia juga menerima upah sebesar Rp 1.175.000,00 (satu juta seratus tujuh puluh lima ribu rupiah) setiap bulannya. Walau jumlah itu belum sesuai dengan upah minimum regional Jakarta, tetapi B3 cukup puas dengan upahnya tersebut, karena jika dibandingkan dengan upahnya semasa bekerja di Rektorat US, maka gajinya di rektorat hanya sebesar Rp 700.000,00 (tujuh ratus ribu rupiah) (wawancara, November 2015 dan November 2017). Jumlah sebesar itupun didapatkannya hanya apabila tidak ada pemotongan.

Menurut keterangan dari buruh B1, buruh B2, dan buruh B3 yang peneliti mintakan pendapatnya, semua buruh petugas kebersihan tersebut mengatakan bahwa mereka belum terdaftar dalam program jaminan sosial tenaga kerja (JAMSOSTEK), sementara pada Pasal 99 Undang-Undang Nomor 13 Tahun 2003 dikatakan bahwa setiap pekerja atau buruh beserta keluarganya berhak untuk memperoleh jaminan sosial tenaga kerja. Namun, walaupun mereka belum terdaftar dalam jaminan sosial tenaga kerja, mereka mengaku bahwa apabila buruh outsourcing atau keluarganya sakit atau tertimpa musibah, maka mereka pasti menerima bantuan materi dan non materi dari atasan-atasan mereka di Koperasi Fakultas US.

Mengenai masalah tunjangan hari raya, berbeda dengan buruh outsourcing di unit kerja Rektorat US yang hanya memberikan tunjangan hari raya kepada buruh outsourcing-nya di bawah satu bulan gaji pokok mereka, maka para buruh outsourcing yang dipekerjakan oleh Koperasi Fakultas US di unit kerja Fakultas US 
mendapatkan tunjangan hari raya yang sesuai dengan Pasal 4, Pasal 6, dan Pasal 7 Peraturan Pemerintah Nomor 78 Tahun 2015, dan Pasal 3 Peraturan Menteri Tenaga Kerja Nomor PER-04/MEN/1994 tentang Tunjangan Hari Raya Keagamaan bagi Pekerja di Perusahaan, yaitu sebesar upah satu bulan kerja (untuk saat ini, diatur dalam Peraturan Menteri Ketenagakerjaan Nomor 6 Tahun 2016 tentang Tunjangan Hari Raya Keagamaan bagi Pekerja/Buruh di Perusahaan). Selain harapan mereka mengenai jaminan sosial tenaga kerja, responden buruh outsourcing yang bekerja di unit kerja Fakultas US cenderung sudah merasa bahagia, serta dihargai dan dihormati selama bekerja di bawah naungan Koperasi Fakultas US sebagai penyedia jasa buruh outsourcing dalam kurun waktu kurang lebih 2 (dua) tahun ini.

Bersumber pada hasil wawancara peneliti dengan para responden di atas, dapat disimpulkan bahwa terdapat persamaan dan perbedaan dalam hal penerapan sistem outsourcing di 2 (dua) unit kerja yang berada dalam satu lembaga universitas yang diteliti, yaitu US. Para buruh outsourcing di kedua unit kerja tersebut, yaitu di Rektorat US dan Fakultas US, sama-sama masih belum diikutsertakan (didaftarkan) dalam program jaminan sosial tenaga kerja, dan juga sama-sama masih memperoleh upah di bawah upah minimum regional.

Tetapi, di samping persamaan tersebut di atas, terdapat pula beberapa perbedaan yang terjadi dalam praktik outsourcing pada kedua unit kerja yang peneliti amati. Perbedaan pertama dapat dilihat pada jumlah upah yang diberikan kepada para buruh outsourcing. Upah bagi buruh outsourcing yang ditempatkan di unit kerja Fakultas US ternyata lebih besar daripada buruh outsourcing di Rektorat US, walaupun masih sama-sama di bawah upah minimum regional.

Selain itu, ada pula perbedaan mengenai tunjangan hari raya yang diperoleh buruh outsourcing. Buruh outsourcing di unit kerja Fakultas US ternyata memperoleh tunjangan hari raya yang lebih besar daripada yang diperoleh buruh outsourcing di Rektorat US. Tunjangan hari raya yang diperoleh buruh outsourcing di Fakultas US lebih sesuai dengan peraturan perundang-undangan yang berlaku.

Buruh outsourcing di Fakultas US mendapatkan tunjangan hari raya yang sesuai dengan Pasal 3 Peraturan Menteri Tenaga Kerja Nomor PER-04/MEN/1994 tentang Tunjangan Hari Raya Keagamaan bagi Pekerja di Perusahaan, yaitu sebesar satu bulan gaji (untuk saat ini, diatur dalam Peraturan Menteri Ketenagakerjaan Nomor 6 Tahun 2016 tentang Tunjangan Hari Raya Keagamaan bagi Pekerja/Buruh di Perusahaan), sementara buruh outsourcing di unit kerja Rektorat US hanya mendapatkan tunjangan hari raya sebesar Rp 350.000,00 (tiga ratus lima puluh ribu rupiah).

Tidak kalah pentingnya ialah faktor perhatian atau kepedulian terhadap keadaan para buruh outsourcing. Berdasarkan wawancara peneliti, diperoleh informasi bahwa para buruh outsourcing di unit kerja Fakultas US akan 
mendapatkan bantuan dari atasan-atasan mereka di Koperasi Fakultas US apabila mereka atau keluarga mereka sedang sakit atau mengalami musibah. Beberapa perbedaan tersebut berdampak pada diri buruh sekaligus menimbulkan perbedaan selanjutnya, yaitu perbedaan dalam hal "menerima" penerapan sistem outsourcing pada diri mereka sebagai buruh outsourcing. Para buruh outsourcing yang bekerja di bawah naungan Koperasi Fakultas US merasa bahwa hak-hak mereka sebagai buruh lebih terpenuhi dan mereka juga puas dengan apa yang telah diberikan serta dilakukan oleh Koperasi Fakultas US sebagai penyedia jasa buruh outsourcing. Selain itu, mereka juga merasa lebih dihargai dan dihormati selama bekerja di bawah naungan Koperasi Fakultas US.

Penjelasan terakhir tersebut menunjukkan bahwa persoalan sistem outsourcing memang harus "diimbangi" dengan adanya faktor lain yang lebih humanis. Sistem outsourcing memang sudah terlanjur dianggap sebagai sistem yang tidak memberikan kepastian kepada pihak buruh, hal ini tentunya merupakan sesuatu yang negatif apabila dilihat dari sisi pihak buruh outsourcing. Namun demikian, kekurangan itu bukan lantas harus didiamkan begitu saja. Untuk "mengimbangi" kekurangan yang ada di dalam sistem outsourcing, maka yang diperlukan selanjutnya ialah menyediakan (melakukan) tindakan-tindakan kreatif yang sifatnya lebih humanis yang ditujukan bagi para buruh outsourcing.

\section{KESIMPULAN}

Berdasarkan pembahasan atas pokok permasalahan yang diteliti mengenai praktik outsourcing, maka dapat ditarik simpulan sebagai berikut:

Pertama, praktik outsourcing yang diterapkan di unit kerja Rektorat US dan unit kerja Fakultas US sebenarnya sama-sama masih belum sesuai dengan ketentuan peraturan perundang-undangan yang berlaku, seperti halnya Undang-Undang Nomor 13 Tahun 2003, contohnya ialah dalam hal jumlah upah yang diberikan kepada buruh outsourcing yang masih di bawah upah minimum regional, dan persoalan keikutsertaan pada program jaminan sosial ketenagakerjaan yang belum terlaksana.

Kedua, walaupun praktik outsourcing pada unit kerja di Rektorat US dan Fakultas US sama-sama masih belum sesuai dengan peraturan perundangundangan, namun di antara keduanya ada beberapa hal yang berbeda yang justru ikut berdampak secara positif terhadap "penerimaan" para buruh terhadap sistem outsourcing yang dijalankan. Perbedaan tersebut, antara lain, ialah apabila dibandingkan dengan unit kerja di Rektorat US, maka di unit kerja Fakultas US, jumlah upah yang diberikan serta tunjangan hari raya yang diperoleh buruh outsourcing lebih besar. Selain itu, juga ada sikap peduli dari atasan mereka, dalam hal ini para pengurus Koperasi Fakultas US, terhadap keadaan para buruh outsourcing, misalnya ketika mereka sedang sakit atau mengalami musibah. Beberapa perbedaan itu akhirnya berdampak positif dalam "menerima" pemberlakukan sistem outsourcing pada diri buruh outsourcing. Buruh outsourcing yang bekerja di bawah naungan Koperasi Fakultas US juga lebih merasa bahwa hak- 
hak mereka sebagai buruh terpenuhi atau diperhatikan dengan baik oleh atasan mereka.

\section{DAFTAR PUSTAKA}

\section{a. Buku}

Arizona, Yance; Wijaya, Endra; Sebastian, Tanius (2014). Pancasila dalam Putusan Mahkamah Konstitusi. Jakarta: Epistema Institute.

Asyrof, H.A. Mukhsin (2003). Membedah Perbuatan Melawan Hukum dan Wanprestasi. Jakarta: Raja Grafindo Persada.

Pakpahan, Muchtar \& Pakpahan, Ruth Damaihati (2010). Konflik Kepentingan Outsourcing dan Kontrak dalam Undang-Undang Nomor 13 Tahun 2003. Jakarta: Bumi Intitama Sejahtera.

Yasar, Iftida (2011). Menjadi Karyawan Outsourcing. Jakarta: Gramedia Pustaka Utama.

\section{b. Jurnal}

Andina, Elga (2013). Ketidakpuasan Buruh Alih Daya. Info Singkat Pusat Pengkajian, Pengolahan Data dan Informasi Sekretariat Jenderal Dewan Perwakilan Rakyat Indonesia, 5(9).

Julianti, Lis (2015). Perlindungan Hukum terhadap Tenaga Kerja Outsourcing di Indonesia. Jurnal Advokasi, Vol. 5(1).

Khairani (2014). Kedudukan Outsourcing Pasca Putusan Mahkamah Konstitusi Nomor 27/PUU-IX/2011. Jurnal Konstitusi, 11(4).

Kunarti, Siti (2009). Perjanjian Pemborongan Pekerjaan (Outsourcing) dalam Hukum Ketenagakerjaan. Jurnal Dinamika Hukum, 9(1).

Mebang, Desi Natalia (2015). Penerapan Perjanjian Kerja bagi Pekerja Alih Daya (Outsourcing) pada PT. PLN (Persero) Area Samarinda. Jurnal Elektronik Administrasi Publik, 3(5).

Munir, Abdul (2014). Viktimisasi Struktural terhadap Buruh Melalui Sistem Outsourcing (Studi Kasus Buruh Outsourcing PT (X) yang Dipekerjakan pada PT (Y) di Kabupaten Serang, Provinsi Banten). Jurnal Sosiologi, 16(2).

Nopiando, Bambang (2012). Hubungan antara Job Insecurity dengan Kesejahteraan Psikologis pada Karyawan Outsourcing. Journal of Social and Industrial Psychology, 1(2).

Soegianto; Yuliana, Marsha \& Sutanto, Eddy M. (2013). Penerapan Strategi Alih Daya (Outsourcing) di UD. Puyuh Plastik Ditinjau dari Ketentuan Perundangan dan Etika Bisnis. Jurnal Agora, 1(1).

Triyono (2011). Outsourcing dalam Perspektif Pekerja dan Pengusaha. Jurnal Kependudukan Indonesia, 6(1).

Utomo, St. Laksanto (2014). Permasalahan Outsourcing dalam Sistem Ketenagakerjaan di Indonesia. Jurnal Lex Publica, 1(1).

\section{c. Peraturan Perundang-Undangan}

Undang-Undang Nomor 13 Tahun 2003 tentang Ketenagakerjaan. 
Peraturan Pemerintah Nomor 78 Tahun 2015 tentang Pengupahan.

Peraturan Menteri Tenaga Kerja Nomor PER-04/MEN/1994 tentang Tunjangan Hari Raya Keagamaan bagi Pekerja di Perusahaan.

Peraturan Menteri Ketenagakerjaan Nomor 6 Tahun 2016 tentang Tunjangan Hari Raya Keagamaan bagi Pekerja/Buruh di Perusahaan.

Keputusan Menteri Tenaga Kerja dan Transmigrasi Nomor KEP.101/MEN/VI/2004 tentang Tata Cara Perizinan Perusahaan Penyedia Jasa Pekerja atau Buruh.

Keputusan Menteri Tenaga Kerja dan Transmigrasi Nomor KEP. 220/MEN/X/2004 tentang Syarat-Syarat Penyerahan Sebagian Pelaksanaan Pekerjaan kepada Perusahaan Lain.

Kitab Undang-Undang Hukum Perdata (Burgerlijk Wetboek). Diterjemahkan oleh R. Subekti dan R. Tjitrosudibio (1996). Jakarta: Pradnya Paramita. 